American Journal of Biochemistry and Biotechnology 4 (4): 438-441, 2008

ISSN 1553-3468

(C) 2008 Science Publications

\title{
Gastroprotective Effects of Melastoma malabathricum Aqueous Leaf Extract against Ethanol-Induced Gastric Ulcer Iin Rats
}

\author{
${ }^{1}$ Fouad Hussain, ${ }^{2}$ Mahmood Ameen Abdulla, ${ }^{2}$ Suzita Mohd Noor, \\ ${ }^{2}$ Salmah Ismail and ${ }^{3}$ Hapipah Mohd Ali \\ ${ }^{1}$ Department of Oral Pathology, Oral Medicine and Periodontology, Faculty of Dentistry, \\ University Technology Mara, Malaysia \\ ${ }^{2}$ Department of Molecular Medicine, Faculty of Medicine \\ ${ }^{3}$ Department of Chemistry, Faculty of Science, University Malaya 50603 \\ Kuala Lumpur, Malaysia
}

\begin{abstract}
The gastro-protective effects of the aqueous leaf extract of Melastoma malabathricum was investigated against ethanol-induced gastric mucosal injuries in rats. There were four groups of adult sprague dawley rats, consisting of six rats per group. Macroscopically, oral administration of absolute ethanol to rats that had been pre-treated with only distilled water significantly produced extensive lesions of the gastric mucosa. Oral pre-treatment with either $250 \mathrm{mg} \mathrm{kg}^{-1}$ of M. malabathricum extract, $500 \mathrm{mg} \mathrm{kg} \mathrm{kg}^{-1}$ of $M$. malabathricum extract, or $20 \mathrm{mg} \mathrm{kg}$-1 of omeprazole 60 minutes before administration of absolute ethanol significantly reduced the formation of gastric mucosal injuries. The observed protection was significant and dose dependent in inhibiting ethanol-induced gastric ulcers. Microscopically, rats that had been pre-treated with only distilled water showed marked damage of the gastric mucosa, induced submucosal edema and leucocytes infiltration. However, animals that had been pre-treated with aqueous leaf extracts or omeprazole showed marked reduction of gastric mucosal damage, reduction of oedema and less leucocyte infiltration of submucosal layer. The results indicated that $500 \mathrm{mg} \mathrm{kg}^{-1}$ aqueous leaf extract of $M$. malabathricum provided the best protection to the gastric mucosa in rats against ethanol-induced gastric ulcers.
\end{abstract}

Keywords: Melastoma malabathricum; gastric ulcer; Omeprazole; histology

\section{INTRODUCTION}

Melastoma malabathricum L. (Melastomataceae) is a common weed found throughout Malaysia. Different parts of the plants are used in folklore remedies for the treatment of various human aliments. The crude extract of M. malabathricum has been used in the treatment of diarrhoea as an astringent and is also used for postpartum treatment and for haemorrhoids ${ }^{[1]}$. Some metabolites isolated from the Melastoma plant have also been reported to have antiviral and cytotoxic activity ${ }^{[2]}$ anti-helmethic and anti-spasmodic action $^{[3]}$, anti-nociceptive, anti-inflammatory and antipyretic properties ${ }^{[4]}$, anti-oxidant and anti-cancer activity $^{[5]}$ and anti-hypertensive activity ${ }^{[6]}$. However, there is no data available regarding the anti-ulcerogenic activity of the $M$. malabathricum L. leaf extract. Therefore, the present study was undertaken to evaluate the anti-ulcerogenic property of the aqueous leaf extract of M. malabathricum in rats.

\section{MATERIALS AND METHODS}

Omeprazole: The reference anti-ulcer drug, omeprazole was obtained from the University Malaya Medical Centre (UMMC). The drug was dissolved in distilled water and administered orally to animals at a concentration of $20 \mathrm{mg} \mathrm{kg}^{-1}\left(5 \mathrm{~mL} \mathrm{~kg}^{-1}\right)$.

Aqueous Extraction: M. malabathricum leaves were collected from different localities around the University of Malaya campus and identified by comparison with specimens available at the Herbarium of Rimba Ilmu, Institute of Science Biology, University of Malaya. The leaves were washed with distilled water and then dried in an incubator at $50^{\circ} \mathrm{C}$ for 5-7 days. The dried leaves were ground to a powder before being extracted by maceration in distilled water (100 g $1500 \mathrm{~mL}^{-1}$, w/v) for 5 days at $37^{\circ} \mathrm{C}$. The extract was then filtered using a filter funnel and the excess water was evaporated under

Corresponding Author: Fouad Hussain, Department of Restorative Dentistry, Faculty of Dentistry, University Technology Mara, 40450 Shah Alam, Selangor Malaysia Tel: +603 55435818 Fax: +603 55435803 
reduced pressure in an EYELA rotary evaporator. Once suitably evaporated, the extract was frozen at $-80^{\circ} \mathrm{C}$ before being subjected to freeze drying to produce a dry extract. The dry extract was then stored at $-20^{\circ} \mathrm{C}$ until use. The extract was dissolved in distilled water and administered to rats in a concentration of 250 and $500 \mathrm{mg} \mathrm{kg}^{-1}$ body weight $\left(5 \mathrm{~mL} \mathrm{~kg}^{-1}\right)$ respectively.

Experimental animals: Adult male sprague-dawley rats were obtained from the Faculty of Medicine, University of Malaya's animal house (Ethic No. PM 28/09/2007 MAA (R)). Animals weighing 180-200 grams were deprived of food for 48 hours but they were allowed free access to tap water until 2 hours before the experiment. During the fasting period, the animals were placed individually in cages with wide-mesh wire bottoms to prevent coprophagy. On the day of experiment, the rats were randomly divided into 4 groups of 6 animals each.

Animal treatment: All rats were treated by orogastric intubations. Negative control rats (Group 1) received $5 \mathrm{~mL} \mathrm{~kg}^{-1}$ distilled water; Group 2 rats received $250 \mathrm{mg} \mathrm{kg}^{-1}$ of M. malabathricum extract $\left(5 \mathrm{~mL} \mathrm{~kg}^{-1}\right)$; Group 3 rats received $500 \mathrm{mg} \mathrm{kg}^{-1}$ of M. malabathricum extract $\left(5 \mathrm{~mL} \mathrm{~kg}^{-1}\right)$; and Group 4 rats, the positive control, received $20 \mathrm{mg} \mathrm{kg}^{-1}$ of omeprazole $(5 \mathrm{~mL}$ $\mathrm{kg}^{-1}$ ); Sixty minutes after this pre-treatment, all rats were gavaged with absolute ethanol $\left(5 \mathrm{~mL} \mathrm{~kg}^{-1}\right)$ and after an additional 60 minutes, the rats were all sacrificed by overdose of diethyl ether. Rat stomachs were rapidly excised and opened along the greater curvature, washed with distilled water and fixed in $10 \%$ buffered formalin.

Gross gastric lesions evaluation: Each stomach was opened along the greater curvature and rinsed with distilled water to remove the gastric contents. The mucosa was examined under a dissecting microscope $(1.8 \mathrm{x})$ with a square-grid eyepiece (big square: Length $\mathrm{X}$ width $=10 \mathrm{X} 10 \mathrm{~mm}^{2}=$ Ulcer area) to assess the formation of hemorrhagic lesions. The length and width (area) of each lesion was determined and the sum of the area of all lesions, in $\mathrm{mm}^{2}$ for each stomach was expressed as the ulcer area $\left(\mathrm{mm}^{2}\right)$. The ulcer area was calculated as described by Kauffman and Grossman ${ }^{[7]}$. The inhibition percentage was calculated using the following formula ${ }^{[8]}$ :

$$
(\% \mathrm{I})=\left[\left(\mathrm{UA}_{\text {control }}-\mathrm{UA}_{\text {treated }}\right) \div \mathrm{UA}_{\text {control }}\right] \times 100
$$

Histological lesions evaluation: The gastric wall specimens were fixed in $10 \%$ buffered formalin and processed to produce paraffin wax tissue sections. The stomach was assessed for damage by examining $5 \mu \mathrm{m}$ sections stained with hematoxylin and eosin.

Statistical analysis: All values are reported as mean \pm SEM and the statistical significance of differences among groups were assessed using one-way ANOVA. A value of $\mathrm{p}<0.05$ was considered significant.

\section{RESULTS}

Gross examination: The present study demonstrated that oral administration with the extract ( 250 or $500 \mathrm{mg} \mathrm{kg}{ }^{-1}$ ) significantly prevented the formation of gastric mucosal ulcers and reduced ulcer formation in a dose dependent manner compared to animals administered with only distilled water (Table 1, Fig. 1 and 2). The present study also showed that the oral feeding of rats with $20 \mathrm{mg} \mathrm{kg}^{-1}$ omperazole or $500 \mathrm{mg} \mathrm{kg}^{-1}$ extract resulted in higher protection for the gastric mucosa compared to rats administered with only $250 \mathrm{mg} \mathrm{kg}^{-1}$ of extract (Table 1). There were no significant differences between the cytoprotective abilities of the animals treated with $20 \mathrm{mg} \mathrm{kg}^{-1}$ omeprazole compared to the animals treated with $500 \mathrm{mg} \mathrm{kg}^{-1}$ extract.

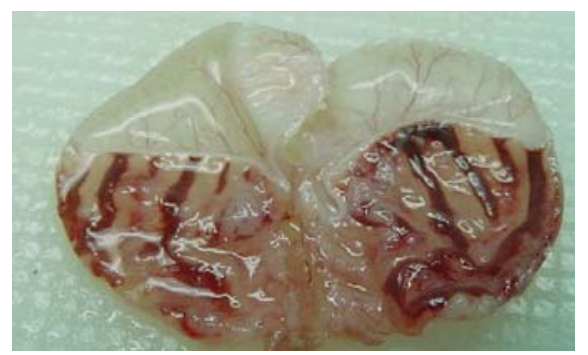

Fig. 1: Severe macroscopic necrosis of gastric mucosa in negative control animals. Severe lesion of the corpus caused by absolute ethanol

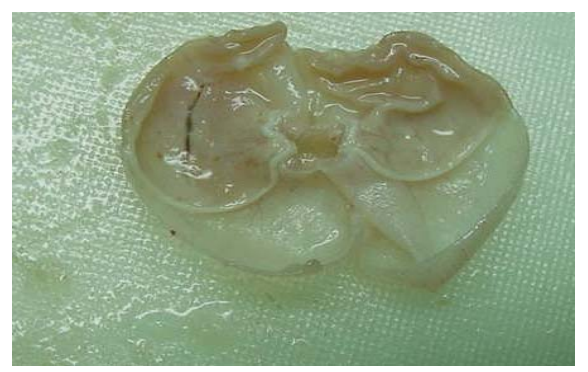

Fig. 2: Mild macroscopic injury of gastric mucosa in (500 mg kg ${ }^{-1}$ ) extract treated animals. Near complete inhibition of gastric lesion formation 
Table 1: Tabulated results of gross examination of all oral treatment

\begin{tabular}{llll}
\hline $\begin{array}{l}\text { Animal } \\
\text { groups }\end{array}$ & Pre-treatment & $\begin{array}{l}\text { Ulcer area } \\
(\mathrm{mm})^{2} \\
(\mathrm{mean} \pm \mathrm{SEM})\end{array}$ & $\begin{array}{l}\text { Inhibition } \\
(\%)\end{array}$ \\
\hline 1 & Distilled water (Control) & $845 \pm 52.17^{\mathrm{a}}$ & - \\
2 & M. malabathricum $\left(250 \mathrm{mg} \mathrm{kg}^{-1}\right)$ & $210 \pm 8.17^{\mathrm{b}}$ & 75.15 \\
3 & M. malabathricum $\left(500 \mathrm{mg} \mathrm{kg}^{-1}\right)$ & $70.00 \pm 8.27^{\mathrm{c}}$ & 91.72 \\
4 & Omeprazol $\left(20 \mathrm{mg} \mathrm{kg}^{-1}\right)$ & $30 \pm 5.32^{\mathrm{c}}$ & 96.45 \\
\hline
\end{tabular}

All values are expresses as mean and standard error mean. Means with different superscripts are significantly different $(\mathrm{p}<0.05)$

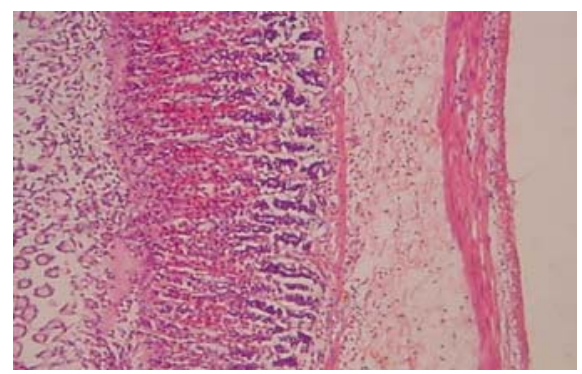

Fig. 3: Histological section of gastric mucosa in negative control animals ( $\mathrm{H}$ and $\mathrm{E}$ stain, 40x). Severe disruption of the surface epithelium. Extensive edema of the submucosa and leucocytes infiltration

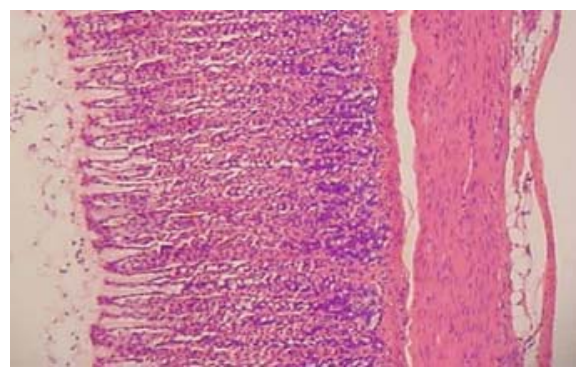

Fig. 4: Histological section of gastric mucosa in animals pre-treated with $M$. malabathricum extract (500 $\left.\mathrm{mg} \mathrm{kg}^{-1}\right)(\mathrm{H}$ and E stain, 40x). Mild disruptions of surface epithelium. No presence of submucosal edema and leucocytes infiltration

Microscopic Examination: The present study demonstrated that rats treated with $20 \mathrm{mg} \mathrm{kg}^{-1}$ omeprazole or extract ( 250 and $500 \mathrm{mg} \mathrm{kg}^{-1}$ ) showed marked prevention of gastric mucosal ulcer, lack of submucosal oedema and no leukocyte infiltration compared to animals treated with only distilled water (Fig. 3 and 4).

\section{DISCUSSION}

The present study demonstrateed that the oral administration of omeprazole or M. malabathricum extract significantly protected the gastric mucosa in rats, compared to the rats administered with only distilled water. Oxidative stress plays a major role in the pathogenesis of various diseases including gastric ulcers. Oxidative stress can damage many biological molecules. The $M$. malabathricum flower extract possesses anti-nociceptive; anti-inflammatory and antipyretic activities and thus the ulcer prevention could be attributed to these properties and supports previous claims on its traditional uses to treat various ailments ${ }^{[4]}$. M. malabathricum flower extract has been shown to contain anti-oxidant cytotoxic flavonoids which may mediate the protection of gastric mucosa ${ }^{[5]}$. Antioxidants have been reported to play a significant role in preventing gastric ulcers. It has appeared that antioxidants may be an important contributory factor in the protection of gastric mucosa ${ }^{[5]}$. Studies have shown that anti-oxidants significantly strengthen the gastric walls and protect tissue from oxidative damage ${ }^{[9]}$. Antiulcerogenic properties of M. malabathricum could also be due to anti-viral and cytotoxic activities ${ }^{[2]}$. M. malabathricum extracts exhibited significant antimicrobial activity and properties that support folkloric use in the treatment of some diseases. This probably explains the use of these plants by the indigenous people against a number of infections ${ }^{[2]}$. Based on the results obtained, it can be concluded that M. malabathricum flower extract is potentially an antiulcerogenic agent that protects and strengthens the gastric mucosa. The exact mechanism of action is not known but it could be due to large quantity of mucous secreted by the gastric mucosa which acts as a mechanical barrier.

\section{ACKNOWLEDGMENT}

This study was financially supported by the University of Malaya through a grant 12-02-03-2051 Science Fund RMK-9 Cycle 1/2008.

\section{REFERENCES}

1. Burkill, I.H., 1996. A dictionary of the economic products of the Malaya Peninsula. 1st Edn., Kuala Lumpur, Singapore, pp: 1462-1464.

2. Lohezic-Le, F., A. Devehat, C. Bakhtiar, M. Bezivin, Amoros and J. Boustie 2002. Antiviral and cytotoxic activities of some Indonesian plants. Fitoterapia, 73: 400-405. DOI: 10.1016/S0367326X(02)00125-9.

3. Osman, K., H.I. Faridah, Z.A. Ibrahim and A. Latif, 2002. A Guide Book to Medicinal Plants of Perlis. 1st Edn., Jabatan Perhutanan Negeri Perlis, Kangar, Perlis, ISBN: 9834065337, pp: 139. 
4. Zakaria, Z.A., R.N. Raden Mohd Nor, G. Hanan Kumar, Z.D. Abdul Ghani, M.R. Sulaiman, G. Rathna Devi, A.M. Mat Jais, M.N. Somchi and C.A. Fatimah, 2006. Antinociceptive, anti-inflammatory and antipyretic properties of $M$. malabathricum leaves aqueous extract in experimental animals. Can. J. Physiol. Pharmacol., 84: 1291-1299. http://www.ingentaconnect.com/content/nrc/cjpp/2 006/00000084/00000012/art00011.

5. Susanti, D., H.S. Sirat, F. Ahmad, R.M. Ali, N. Aimi and M. Kitajima, 2007. Antioxidant and cytotoxic flavonoids from the flowers of Melastoma malabathricum L. Food Chem., 103: 710-716. DIO: 10.1016/j.foodchem.2006.09.011.

6. Cheng, J.T., F.L. Hsu and H.F. Chen, 1993. Antihypertensive principles from the leaves of Melastoma candidum. Planta. Med., 59: 405-407. http:/cat.inist.fr/?aModele=afficheN\&cpsidt=3766227.
7. Kauffman, G.L. and M.I. Grossman, 1978. Prostaglandin and cimetidine inhibit the formation of ulcers produced by parenteral salicylates. Gastroenterology, $\quad$ 75: 1099-2102. http://www.ncbi.nlm.nih.gov/pubmed/361490.

8. Njar, V.C.O., J.K. Adesanwo and Y. Raji Methyl Angolensate, 1995. The antiulcer agent of the stem bark of Entandrophragma angolense. Planta Med., 61: 91-92. http://www.ncbi.nlm.nih.gov/pubmed/7701005

9. Martin, A., 1996. The use of antioxidants in healing. Dermatol. Surg., 22: 156-160. http://grande.nal.usda.gov/ibids/index.php?mode2= detail\&origin=ibids_references\&therow $=109810$. 